\title{
Reproductive biology of the small-scaled terapon, Terapon puta (Cuvier, 1829), from Lake Timsah, Egypt
}

\author{
William Rizkalla ${ }^{1}$; Hamza, A. El-Shabaka ${ }^{1}$; Azza, A. El-Ganiany ${ }^{2}$; Fawzia, A. A. \\ Abd El-Rahman ${ }^{1}$ and Marwa, M. El-Naggar ${ }^{1}$ \\ 1. Zoology Department, Faculty of Science, Ain Shams University, Egypt. \\ 2. National Institute of Oceanography and Fisheries, Egypt.
}

\section{ABSTRACT}

The reproductive biology of the small-scaled terapon, Terapon puta (Cuvier, 1829), from Lake Timsah, Ismailia Governorate, Egypt, has been studied during the period from June 2011 to May 2014. The results revealed that the growth of the total body weight relative to the total body length is negative allometric ( $b=2.4954)$. Moreover, the collected fishes were divided into three age groups from one to three years. The age composition of $T$. puta catch indicated that individuals belonging to age group two have predominated the fish population $(90.53 \%$ of the total collected individuals). The overall sex ratio indicated that the females $T$. puta were dominant throughout all the seasons of the year. The average values of the gonadosomatic index of $T$. puta were small in winter (the pre-spawning season) for both sexes, while they gradually increased in spring and summer to reach highest values in summer. The values of GSI then decreased gradually to reach minimal values in autumn (the postspawning season) for both sexes. The aforementioned data indicates that $T$. puta has a long spawning season that starts in early spring and ends in late summer. Moreover, the study of the fecundity of $T$. puta revealed that the highest significant relationship was found between the logarithmic values of both mean total body weight, and mean observed absolute fecundity, with highest correlation coefficient $\left(r^{2}=0.999\right)$, consequently, the total body weight was the best indicator of the fecundity of $T$. puta. The recommendation of the present study is to prevent fishing of $T$. puta in Lake Timsah during the spawning season, which extends from April to August, or use nets with wider meshes in order to protect the spawning biomass of T. puta resources.

Keywords: Terapon puta, fecundity, gonadosomatic index, allometric growth, otolith, sex ratio.

\section{INTRODUCTION}

The Small-scaled terapon, Terapon puta (Cuvier,1829), is considered an important commercial fish in the Indo-West Pacific, North Indian Ocean and the IndoAustralian Archipelago. It is a Lessepsian migrant, and now is prevalent in the Mediterranean Sea (Golani et al., 2002). This species belongs to Order: Perciformes and Family: Terapontidae. This family includes 16 genera and about 48 fish species (Nelson, 2006). The species of this family are frequent in the marine coastal, brackish and fresh water.

Holden and Raitt (1974) stated that knowledge of the fecundity of a species is an important factor in fish stock management and it is used to calculate the reproductive potential of a stock and the survival from egg to recruitment.

Miu et al. (1990) stated that the sex ratio of Terapon jarbua, from Tamshui River is in favor of the females and the overall sex ratio of females to males is 1.8:1. On the other hand, Nandikeswari et al. (2013) observed that males T. puta, from Puducherry (Pondicherry) coast are dominant in the population and the overall sex 
ratio of females to males is 1:1.06. In addition, Nandikeswari et al. (2014 a) reported that the males Terapon jarbua, from Pondicherry coast outnumber the females and the overall sex ratio of females to males is 1:1.28. Moreover, Vicentini and Araujo (2003) pointed out that the sex ratio constitutes basic information necessary for the assessment of the potential of fish reproduction and the stock size estimation in fish population.

Taskavak and Bilecenoglu (2001) stated that the growth in weight relative to length in Pelates quadrilineatus, from the eastern Mediterranean Sea, is isometric. However, Edelist (2012) and Isa et al. (2012) observed a negative allometric growth in T. puta, from the southeastern Mediterranean Sea and Terapon jarbua, from the Merbok estuary, respectively.

Nandikeswari and Anandan (2013), in T. puta, from Nallavadu coast and Nandikeswari et al. (2014 a), in Terapon jarbua, from Pondicherry coast, found that a highly significant relationship between the logarithmic values of both the fecundity and the gonad weight. So, the gonad weight is considered as the best indicator of the fecundity.

Therefore, the present study was planned to gain more information about the biological aspects of $T$. puta during the different seasons of the year that will help in the management and improvement of its fishery.

\section{MATERIALS AND METHODS}

\section{1- Sampling:}

A total number of 441 specimens of female and male Terapon puta (Cuvier, 1829) (Perciformes: Terapontidae) were collected seasonally and obtained alive from the fishermen operating by trammel nets in Lake Timsah in Ismailia governorate (Fig. 1). In the present work, the specimens were collected during three consecutive years from June 2011 to May 2014 targeting the accuracy of the obtained data.

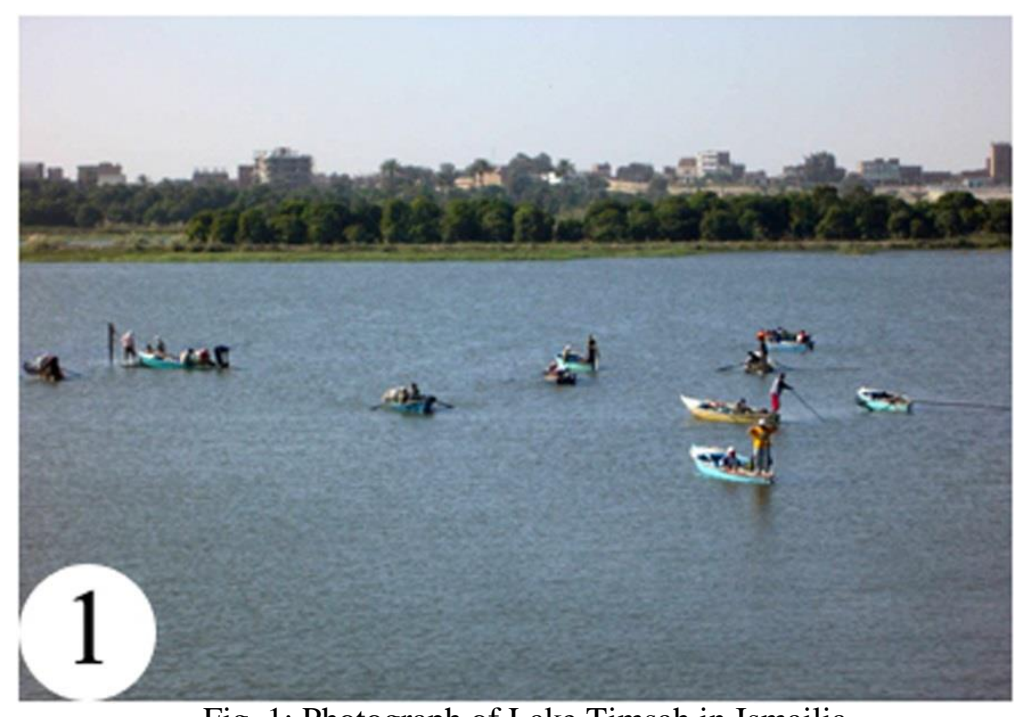

Fig. 1: Photograph of Lake Timsah in Ismailia.

\section{2- The length-weight relationship:}

The length of each fish was measured to the nearest $0.1 \mathrm{~cm}$, while the body weight was measured to the nearest $0.1 \mathrm{gm}$. Moreover, the relationship between the length and the weight of $T$. puta was analyzed. The statistical relationship between these parameters was established using the formula of Le Cren (1951): 


$$
\mathrm{W}=\mathrm{a} \mathrm{L}^{\mathrm{b}}
$$

Where, W: is the fish total body weight in gm.

$\mathrm{L}$ : is the fish total body length in $\mathrm{cm}$.

a: is a constant (intercept) which varies for any given species.

b: is the growth exponent (slope).

\section{3-The age and growth:}

\section{i- The age determination:}

Most of the authors preferred to use scales for the age determination. In the present study, it was difficult to collect scales, since the scales of T. puta are small and loosely embedded structures with hardly visible annual marks; therefore in the present study, otoliths were used for the age determination. Before aging, otoliths were cleaned by $8 \% \mathrm{HCl}$, and then dried. The otoliths were cleared in a mixture of $50 \%$ ethyl alcohol and $50 \%$ glycerin and they were examined using Optika 4083 P3 microscope. The opaque and transparent rings were counted from the nucleus to the margin along the longest axis of the otolith. One opaque zone together with one transparent zone were considered to be an annual increment. Each annual increment represents one year of the fish age (El-Ganainy, 1992).

\section{ii- The age composition:}

The number of fish in each age group was calculated, then the proportion of the different age groups of the fish in the catch was used to calculate the age composition of T. puta.

\section{4- The sex ratio:}

Each specimen was dissected and the gonads were removed. The sex of each specimen was identified by examination of the gonads. The proportion of the two sexes relative to one another was used to calculate the sex ratio.

\section{5- The gonadosomatic index:}

The gonadosomatic index (GSI) was calculated according to Strum (1978) as follows: $\mathrm{GSI}=\frac{\text { weight of gonad }}{\text { Total body weight }} \times 100$

\section{6- The fecundity:}

In the present study, analysis of 29 mature female ovaries was carried out. The ovaries were preserved in $10 \%$ neutral formalin; the two ovaries were then weighed. It was found convenient to take the central region of each ovary as a representative subsample for the fecundity. A sub-sample of about 0.1 to $0.2 \mathrm{gm}$ from each ovary was weighed to the nearest $0.001 \mathrm{gm}$ and then crumbled in a large petri-dish containing glycerol. The number of the mature ova that are likely to be spawned in each subsample was counted. Two terms are applied in studying the fish fecundity, namely: the absolute fecundity which is the total number of mature oocytes in the ovary and the relative fecundity which is the total number of oocytes per unit of fish length or weight (Nikolsky, 1963). The absolute and relative fecundities can be calculated using the following equations:

$$
\begin{aligned}
& \text { The absolute fecundity }=\frac{\text { Ovary weight } x \text { number of oocytes in the sub-sample }}{\text { weight of ovary sub-sample }} \\
& \text { The relative fecundity }=\frac{\text { Absolute fecundity }}{\text { total body length or weight }}
\end{aligned}
$$

\section{The statistical analysis:}

Microsoft Office Excel in the personal computer (PC) windows (2010) was used and the analysis of variance (ANOVA) test is included in the regression analysis and was used to test whether the calculated regression line was significant or not. 


\section{RESULTS}

\section{1- The length-weight relationship:}

The total body length of the specimens ranged from 5.6 to $15.2 \mathrm{~cm}$ with an average of $11.282 \pm 1.2512 \mathrm{~cm}$, while the total body weight varied from 5.08 to 41.65 $\mathrm{gm}$, with an average of $19.261 \pm 5.5376 \mathrm{gm}$. The length-weight equation of Le Cren (1951) computed was:

$$
\mathrm{W}=0.0442 \mathrm{~L}^{2.4954}
$$

ANOVA by: $\left(r^{2}=0.9012, \mathrm{No}=441, \mathrm{SE}_{\mathrm{a}}=0.0954, \mathrm{SE}_{\mathrm{b}}=0.0394\right)$.

The average of the observed and calculated total body weights are represented in Table (1) and graphically represented in Figure (2). The agreement between the observed and calculated total body weights is evident from the curve, where the smooth curve represents the calculated weights and the dots represent the observed ones. The growth of total body weight relative to total body length was negative allometric $(b=2.4954 ; 95 \%$ CI: 2.41789-2.5729). A high degree of correlation was found between the logarithms of the total body weight and length, (Fig. 3), which indicated that an equation of the type $\mathrm{W}=\mathrm{a} \mathrm{L}^{\mathrm{b}}$ fits the data well. The derived logarithmic form for Le Cren equation was as follows:

$$
\log \mathrm{W}=-1.3542+2.4954 \log \mathrm{L}\left(\mathrm{r}^{2}=0.9012\right)
$$

Table 1: Average observed and calculated total body weights for each total body length of T. puta from

\begin{tabular}{|c|c|c|c|c|c|}
\hline \multicolumn{2}{|c|}{ Total body length (cm) } & \multirow{2}{*}{$\begin{array}{l}\text { Fish } \\
\text { No. }\end{array}$} & \multicolumn{3}{|c|}{ Total body weight (gm) } \\
\hline Range observed & Average observed & & Range observed & Average observed & Calculated \\
\hline $5.0-5.9$ & 5.70 & 2 & $5.0-5.5$ & 5.45 & 3.40 \\
\hline $6.0-6.9$ & 6.65 & 6 & $5.0-6$ & 5.72 & 4.99 \\
\hline $7.0-7.9$ & 7.51 & 7 & $5.0-6.9$ & 6.31 & 5.88 \\
\hline $8.0-8.9$ & 8.57 & 3 & $7.0-8.5$ & 7.5 & 9.41 \\
\hline $9.0-9.9$ & 9.45 & 19 & $9.7-14.2$ & 11.14 & 12.01 \\
\hline $10.0-10.9$ & 10.55 & 75 & $11.7-19.3$ & 15.56 & 15.81 \\
\hline $11.0-11.9$ & 11.37 & 221 & $14.0-25.5$ & 19.22 & 19.05 \\
\hline $12.0-12.9$ & 12.32 & 85 & $18.3-31.0$ & 23.44 & 23.28 \\
\hline $13.0-13.9$ & 13.28 & 16 & $28.0-37.0$ & 31.10 & 28.07 \\
\hline $14.0-14.9$ & 14.35 & 4 & $31.0-40.5$ & 36.59 & 34.06 \\
\hline $15.0-15.9$ & 15.07 & 3 & $38.7-41.6$ & 39.84 & 38.48 \\
\hline
\end{tabular}
Lake Timsah.

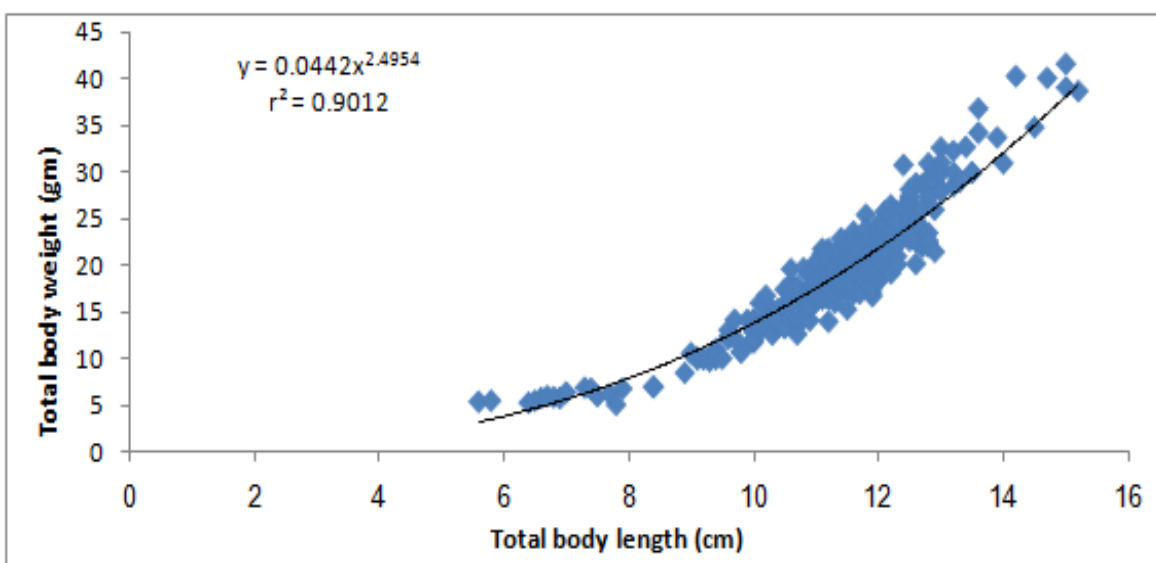

Fig. (2): Total body length-total body weight relationship of $T$. puta from Lake Timsah. 


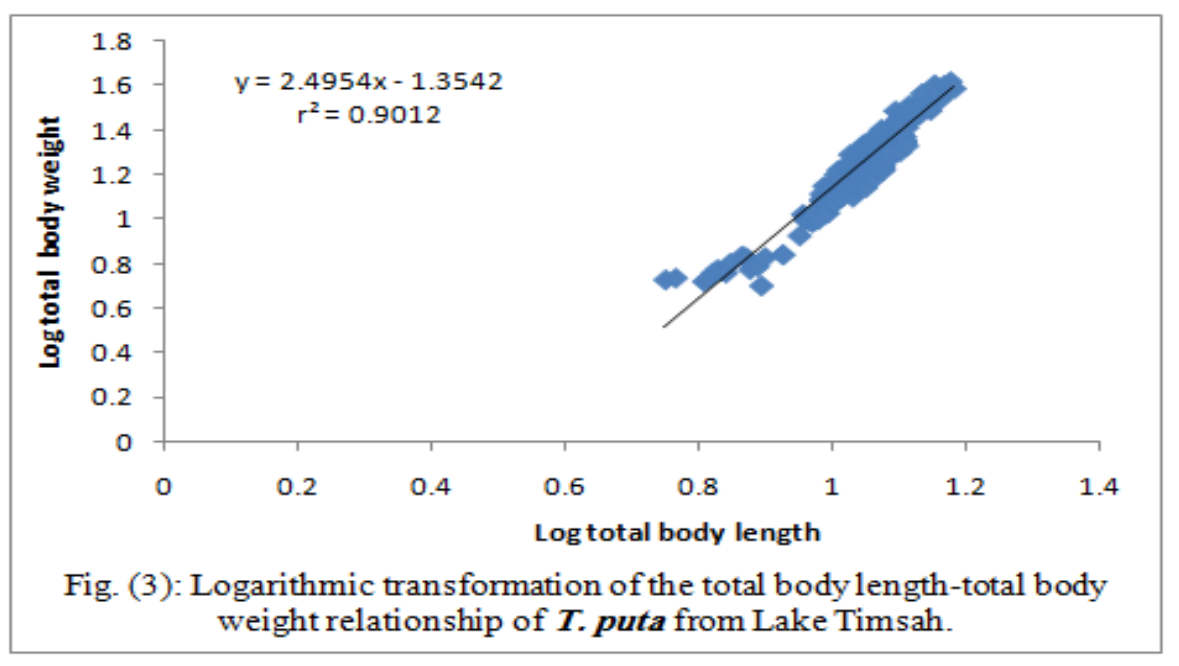

\section{2- The age and growth:}

\section{i- The age determination:}

The otolith of $T$. puta is elliptic in shape, with a rostrum (Rs) and slightly irregular margin (Mr). It is composed of a central nucleus $(\mathrm{N})$ which is surrounded by a number of concentric rings of different radii, forming opaque and translucent zones. One opaque zone (Oq.z) together with a translucent zone (Tr.z) represents an annual ring. Each annual ring accounts for a year of the fish age (Fig. 4).

In the present study, three age groups from I to III years were encountered. The mean observed lengths at the different age groups are $8.71,12.62$ and $14.81 \mathrm{~cm}$, respectively, (Table 2) and this indicates a rapid growth in the $1^{\text {st }}$ year of life as the fish attains more than $50 \%$ of its maximum size, whereas in the following years the rate of growth of the different age groups slows down.

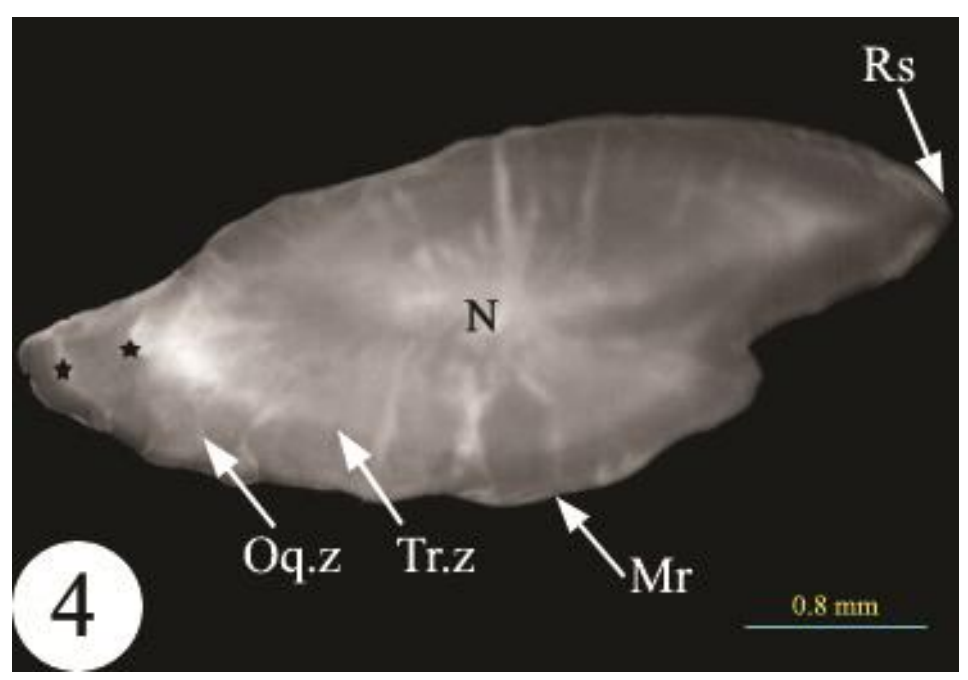

Fig. 4: Photomicrograph of an otolith of T. puta from Lake Timsah belonging age group two. Asterisk: annual ring.

Table 2: The mean observed lengths and standard deviation of different age groups of T. puta from Lake Timsah.

\begin{tabular}{|c|c|c|c|c|}
\hline Age group & $\begin{array}{c}\text { Number of } \\
\text { fish }\end{array}$ & $\begin{array}{c}\text { Observed length range } \\
(\mathbf{c m})\end{array}$ & $\begin{array}{c}\text { Mean observed } \\
\text { length }(\mathbf{c m})\end{array}$ & S.D \\
\hline I & 24 & $7.1-9.8$ & 8.71 & 0.589 \\
II & 392 & $9.5-13.8$ & 12.62 & 0.321 \\
III & 17 & $12.9-15.1$ & 14.81 & 0.258 \\
\hline
\end{tabular}




\section{ii- The age composition:}

The study of the age composition of $T$. puta from Lake Timsah reveals the predominance of age group (II) in the catch (90.53\% of the individuals). The fishes of age groups (I) and (III) are both represented by small percentages of 5.54 and $3.93 \%$, respectively, (Table 3 and Fig. 5).

Table 3: The age composition of T. puta from Lake Timsah.

\begin{tabular}{|c|c|c|}
\hline Age group & Number of fish & \% composition \\
\hline I & 24 & 5.54 \\
II & 392 & 90.53 \\
III & 17 & 3.93 \\
\hline
\end{tabular}

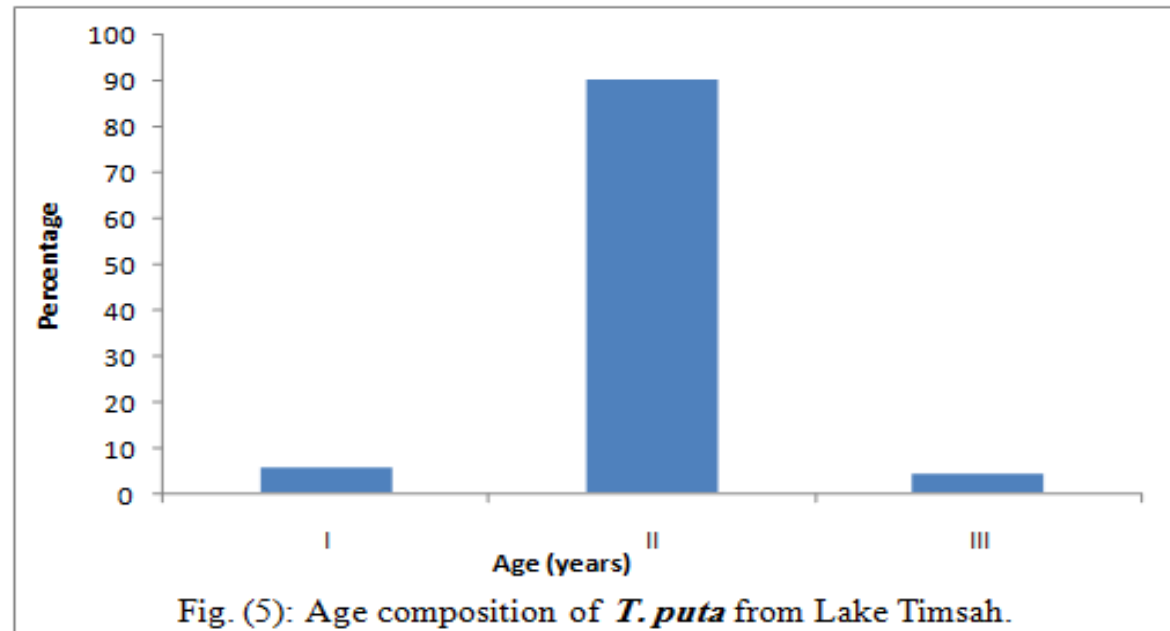

\section{3- The sex ratio:}

The both sexes of $T$. puta are not present in the same proportion throughout the different seasons of the year. The females are dominant during all the seasons of the year and show the highest percentage in Spring with a value of $63.38 \%$. The overall sex ratio of females to males during the study period was 1.3:1, respectively, (Table 4 and Fig. 6).

Table 4: Seasonal sex ratio of T. puta from Lake Timsah.

\begin{tabular}{|c|c|c|c|c|}
\hline \multirow{2}{*}{ Season } & \multicolumn{2}{|c|}{ Females } & \multicolumn{2}{c|}{ Males } \\
\cline { 2 - 5 } & No. & \% & No. & \% \\
\hline Summer & 130 & 53.5 & 113 & 46.5 \\
\hline Autumn & 49 & 56.32 & 38 & 43.68 \\
\hline Winter & 23 & 57.5 & 17 & 42.5 \\
\hline Spring & 45 & 63.38 & 26 & 36.62 \\
\hline
\end{tabular}




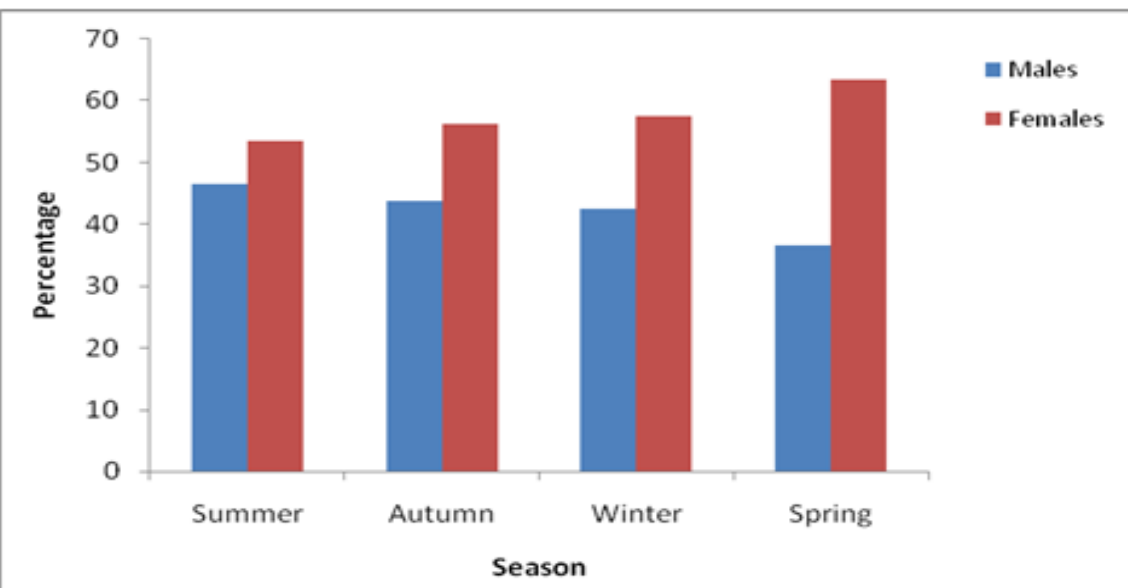

Fig. (6): Seasonal sex ratio of $T$. puta from lake Timsah

\section{4- The gonadosomatic index:}

The average values of gonadosomatic index were small in Winter for both sexes (1.389 for females and 0.337 for males) which is considered as the pre-spawning season and then they increased sharply in Spring and Summer and reached the highest values of 5.356 for females and 3.308 for males in Summer, where the spawning activity was highly observed for both sexes. The values of GSI decreased gradually till they reach the minimal values in Autumn for both sexes $(0.974$ for females and 0.291 for males) which is considered as the post-spawning season for both sexes (Tab. 5) and (Fig. 7). The aforementioned data reveals that $T$. puta has a prolonged spawning season starting from early Spring till late Summer.

Table 5: Seasonal variation in gonadosomatic index of females and males T. puta from Lake Timsah.

\begin{tabular}{|c|c|c|c|c|c|c|}
\hline Season & $\begin{array}{c}\text { No. of } \\
\text { females }\end{array}$ & $\begin{array}{c}\text { Females } \\
\text { GSI }\end{array}$ & S.D & $\begin{array}{c}\text { No. of } \\
\text { males }\end{array}$ & $\begin{array}{c}\text { Males } \\
\text { GSI }\end{array}$ & S.D \\
\hline Winter & 23 & 1.389 & 0.447 & 17 & 0.338 & 0.384 \\
Spring & 45 & 3.589 & 1.863 & 10 & 3.00 & 2.836 \\
Summer & 130 & 5.356 & 1.692 & 113 & 3.308 & 1.795 \\
Autumn & 49 & 0.974 & 0.780 & 38 & 0.291 & 0.536 \\
\hline
\end{tabular}

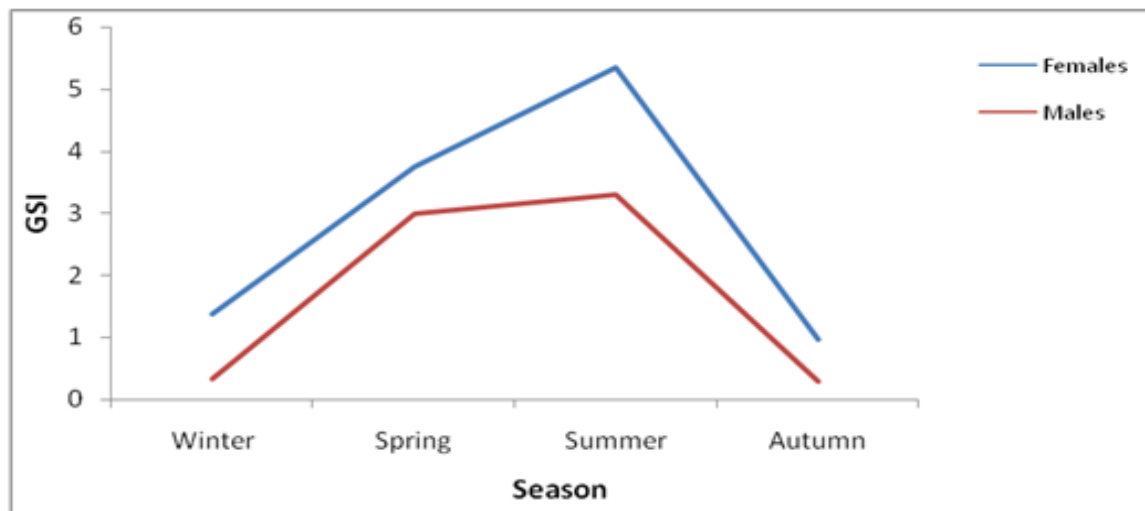

Fig. (7): Seasonal variation of gonadosomaic index of females and males $T$. puta from Lake Timsah

\section{5- The fecundity:}

The relationship between the absolute fecundity and total body length or total body weight was then estimated. To find out the best correlation coefficients between the absolute fecundity and total body length and between the absolute fecundity and total body weight, four mathematical plots were tested. These plots are: arithmetic- 
arithmetic, arithmetic-log, log-arithmetic and log-log. The correlation coefficient " $\mathrm{r}^{2}$ " and the values of the intercept "a" and the regression coefficient " $b$ " for the different plots are given in Table (6).

\section{a- The relationship between the absolute fecundity and the fish total body length:}

It is clear from Table (7) and Figure (8) that the egg production of T. puta increases with the increase in fish total body length. Thus, the mean observed absolute fecundity of $T$. puta ranges between 20437and 45272.83 eggs for fish with the mean total body length ranging from 9.9 to $12.35 \mathrm{~cm}$. Moreover, the mean relative fecundity of $T$. puta increases with the increase in fish mean total body length and ranges from 2064.34 to 3665.82 eggs per each $\mathrm{cm}$.

It is clear from Table (6) that the relationship between the fish total body length and $\log$ observed absolute fecundity has the highest correlation coefficient $\left(\mathrm{r}^{2}=\right.$ 0.994). This relationship is a linear relationship and is represented by the following equation:

$$
\log F=a+b(L)
$$

Where, F: is the calculated absolute fecundity.

$\mathrm{L}:$ is the total body length.

$$
\log F=2.9224+0.1396(\mathrm{~L})
$$

The graphical representation of this relationship is illustrated in Figure (8).

Table 6: The correlation coefficients, the values of the intercepts and the regression coefficients of the relationships between absolute fecundity and total body length $(\mathrm{L})$, and absolute fecundity and total body weight (W) of $T$. puta from Lake Timsah.

\begin{tabular}{|c|c|c|c|c|c|c|}
\hline & \multicolumn{3}{|c|}{$\mathbf{F}$} & \multicolumn{3}{c|}{ Log F } \\
\cline { 2 - 6 } & $\mathbf{r}^{\mathbf{2}}$ & $\mathbf{a}$ & $\mathbf{b}$ & $\mathbf{r}^{\mathbf{2}}$ & $\mathbf{a}$ & $\mathbf{b}$ \\
\hline $\mathbf{L}(\mathbf{c m})$ & 0.9656 & -80054.1 & 10002.14 & 0.9945 & 2.9224 & 0.1396 \\
$\log \mathbf{L}$ & 0.9536 & -233870 & 253719.3 & 0.989 & 0.7629 & 3.5527 \\
\hline W (gm) & 0.999 & -15689.3 & 2461.888 & 0.996 & 3.8951 & 0.03085 \\
$\log \mathbf{W}$ & 0.992 & -116240 & 115703 & 0.999 & 2.6251 & 1.4576 \\
\hline
\end{tabular}

Table 7: Mean observed, calculated absolute and relative fecundity of $T$. puta in relation to the fish total body length.

\begin{tabular}{|c|c|c|c|c|c|}
\hline $\begin{array}{c}\text { Total body } \\
\text { length interval } \\
\text { (cm) }\end{array}$ & $\begin{array}{c}\text { Mean total } \\
\text { body length }\end{array}$ & $\begin{array}{c}\text { Number of } \\
\text { fish }\end{array}$ & $\begin{array}{c}\text { Mean observed } \\
\text { absolute } \\
\text { fecundity }\end{array}$ & $\begin{array}{c}\text { Mean calculated } \\
\text { absolute fecundity }\end{array}$ & $\begin{array}{c}\text { Mean relative } \\
\text { fecundity F/L }\end{array}$ \\
\hline $9.0-9.9$ & 9.9 & 1 & 20437 & 20157.65 & 2064.34 \\
$10.0-10.9$ & 10.59 & 9 & 25046.56 & 25163.09 & 2365.11 \\
$11.0-11.9$ & 11.47 & 13 & 32221.92 & 33389.66 & 2809.23 \\
$12.0-12.9$ & 12.35 & 6 & 45272.83 & 44305.74 & 3665.82 \\
\hline
\end{tabular}

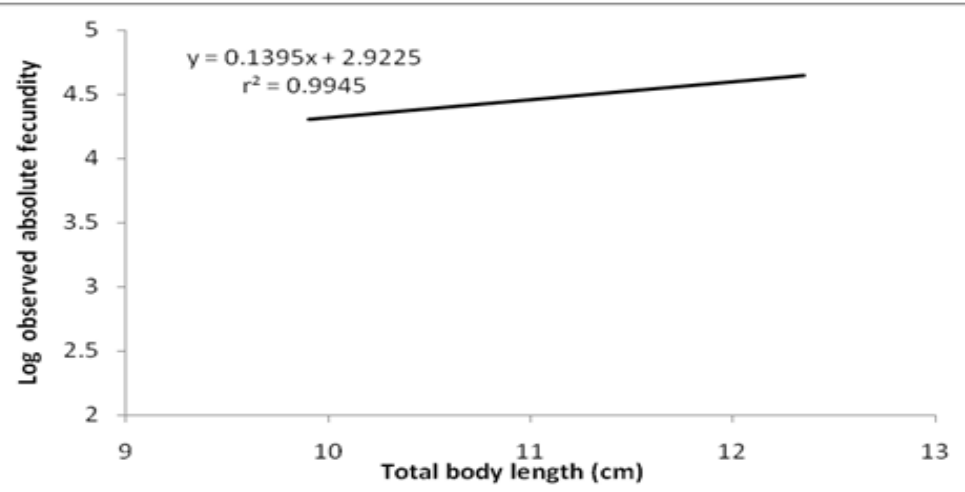

Fig. (8): Relationship between total body length and log observed absolute fecundity of $\boldsymbol{T}$. puta from Lake Timsah. 


\section{b- The relationship between the absolute fecundity and the fish total body weight:}

It is clear from Table (8) and Figure (9) that the values of absolute and relative fecundities increase with the increase in fish total body weight. The values of the mean observed absolute fecundity range from 25190.12 to 46508 eggs for fish with the mean body weight ranging from 16.54 to $25.19 \mathrm{gm}$, while the values of the mean relative fecundity range from 1522.98 to 1846.28 eggs per each gm.

The weights of the 29 fishes selected for fecundity studies were grouped in classes of $5 \mathrm{gm}$ interval. The fecundity data obtained were plotted against the mean total body weight of $T$. puta. Table (6) shows that the highest estimated correlation coefficient is $\left(\mathrm{r}^{2}=0.999\right)$ for the relationship between the logarithmic values of both the fish mean total body weight and the mean observed absolute fecundity. This relationship is a linear relationship and is represented by the following equation:

$$
\log F=a+b(\log W)
$$

Where, $\mathrm{F}$ : is the calculated absolute fecundity

$\mathrm{W}$ : is the total body weight.

$$
\log \mathrm{F}=2.6251+1.476(\log \mathrm{W})
$$

This relationship is graphically represented in Figure (9).

Table 8: Mean observed, calculated absolute and relative fecundity of $T$. puta in relation to the fish total body weight.

\begin{tabular}{|c|c|c|c|c|c|}
\hline $\begin{array}{c}\text { Total body } \\
\text { weight range } \\
\text { (gm) }\end{array}$ & $\begin{array}{c}\text { Mean } \\
\text { total body } \\
\text { weight }\end{array}$ & $\begin{array}{c}\text { Number of } \\
\text { fish }\end{array}$ & $\begin{array}{c}\text { Mean observed } \\
\text { absolute } \\
\text { fecundity }\end{array}$ & $\begin{array}{c}\text { Mean calculated } \\
\text { absolute } \\
\text { fecundity }\end{array}$ & $\begin{array}{c}\text { Mean relative } \\
\text { fecundity F/W }\end{array}$ \\
\hline $14.0-18.9$ & 16.54 & 17 & 25190.12 & 25190.53 & 1522.98 \\
$19.0-23.9$ & 21.15 & 9 & 3637.44 & 36047.27 & 1703.89 \\
$24.0-28.9$ & 25.19 & 3 & 46508 & 46508.27 & 1846.28 \\
\hline
\end{tabular}

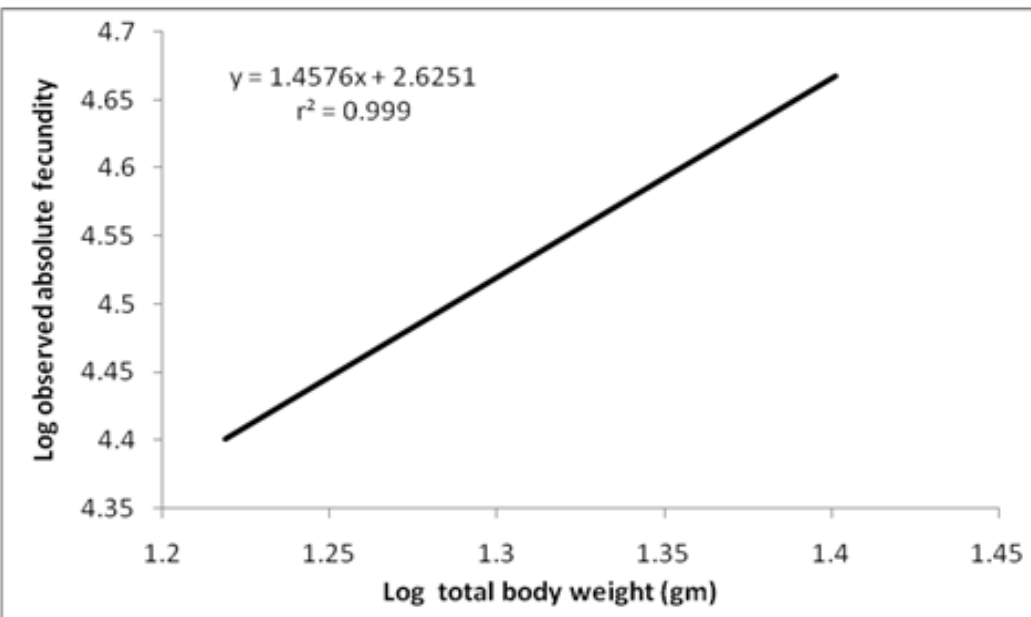

Fig. (9): Relationship between log total body weight and log observed absolute fecundity of $T$. puta from Lake Timsah.

\section{DISCUSSION}

In the present study, the total body length of $T$. puta ranged between 5.6 to 15.2 $\mathrm{cm}$ and the total body weight varied from 5.08 to $41.65 \mathrm{gm}$. Vari (2001) reported that the maximum length of T. puta, from the western central Pacific is $15 \mathrm{~cm}$, while Edelist (2012) stated that the total body length of $T$. puta, from the southeastern Mediterranean Sea ranges from 7.3-14 cm and the maximum total body weight is 28.5 
gm. On the other hand, Nandikeswari and Anandan (2013) pointed out that the total body length of $T$. puta from Nallavadu coast ranges from $13.4-21.9 \mathrm{~cm}$ and the total body weight varies from 30-78 gm. This variability may be due to the difference in the environmental conditions such as: habitat, food abundance and temperature.

The length-weight relationship is very crucial in estimating the standing stock biomass and comparing the development history of fish population from different regions (Petrakis and Stergiou, 1995). It is an important fishery management tool and it is very useful for cultivators and fisheries managers to ascertain the growth of the species (Nandikeswari et al., 2014 b). Length- weight regressions have been used frequently to estimate weight from length because direct weight measurement can be time consuming in the field (Sinovcic et al., 2004). Length-weight relationship differs for the same species in different localities according to the environmental conditions, such as temperature and abundance of food. Table (9) summarizes the results of the length-weight relationships for $T$. puta and the related fish species in different localities.

Table 9: Summary of the recorded length-weight constants and $\mathrm{r}^{2}$ of Pelates quadrilineatus, Terapon jarbua and Terapon puta in different localities.

\begin{tabular}{|c|c|c|c|c|c|}
\hline Fish species & Locality & $\mathbf{a}$ & $\mathbf{b}$ & $\mathbf{r}^{2}$ & Authors \\
\hline $\begin{array}{c}\text { Pelates } \\
\text { quadrlineatus }\end{array}$ & $\begin{array}{c}\text { Eastern } \\
\text { Mediterranean } \\
\text { Sea }\end{array}$ & 0.00000148 & 2.958 & 0.97 & $\begin{array}{c}\text { Taskavak and } \\
\text { Bilecenoglu (2001) }\end{array}$ \\
\hline Terapon jarbua & $\begin{array}{l}\text { Korangi- Phitti } \\
\text { Creek area } \\
\text { (northern } \\
\text { Arabian Sea) }\end{array}$ & -1.914 & 3.091 & 0.969 & Hussainet al. (2010) \\
\hline Terapon jarbua & $\begin{array}{c}\text { Beibu Gulf } \\
\text { (northern South } \\
\text { China Sea) }\end{array}$ & 0.00493 & 2.76 & 0.990 & Wang et al. (2011) \\
\hline Terapon jarbua & $\begin{array}{l}\text { Merbok estuary } \\
\text { Kedah }\end{array}$ & 0.0197 & 2.9279 & 0.9565 & Isa et al. (2012) \\
\hline Terapon jarbua & $\begin{array}{c}\text { The wider Gulf } \\
\text { of Aden }\end{array}$ & 0.0288 & 2.99 & 0.96 & Lavergne et al. (2013) \\
\hline Terapon puta & $\begin{array}{c}\text { Southeastern } \\
\text { Mediterranean } \\
\text { Sea }\end{array}$ & 0.0151 & 2.91 & 0.979 & Edelist (2012) \\
\hline Terapon puta & Lake Timsah & 0.0442 & 2.4954 & 0.9012 & The present study \\
\hline
\end{tabular}

In the present study, the calculated value of " $b$ " is 2.4954 indicating that the growth of weight relative to length is negative allometric. These observations coincide with those recorded in T. jarbua, from Beibu Gulf (Wang et al., 2011), T. puta, from the southeastern Mediterranean Sea (Edelist, 2012) and T. jarbua, from Merbok estuary, Kedah (Isa et al., 2012). However, they disagree with those recorded in Pelates quadrilineatus (Taskavak and Bilecenoglu, 2001) and T. jarbua (Lavergne et al., 2013) in which the length-weight relationship is nearly isometric. On the other hand, the length-weight relationship of $T$. jarbua, from Korangi-Phitti Creek area (northern Arabian Sea) (Hussain et al., 2010) shows positive allometric growth. The value of " $b$ " gives information on the kind of growth of the fish. The growth is isometric if "b" $=3$ and allometric if " $b " \neq 3$ (negative if "b" " $<3$ and positive if "b">3) (Ricker, 1973).

In the present study, otoliths are considered to be the most suitable structure for the aging of T. puta. The otolith of T. puta is elliptic in shape, with a rostrum and slightly irregular margin. These observations contradict with those of Alwany and 
Hassan (2008) who stated that the otolith of T. puta, from Suez Canal and Gulf of Suez is oval in shape, with entire margin and lacks a rostrum. Otoliths are considered to be the most reliable aging structure in some fish species (Staples, 1971 and Khan et $a l ., 2011)$. The suitability of otoliths for age determination is supported by the fact that they do not show reabsorption and their growth is acellular rather by calcification (Secor et al., 1995). Moreover, they are metabolically inert, thus do not reflect physiological changes that occur throughout the life of fish (Phelps et al., 2007).

The present study is the first attempt to determine the age and growth of $T$. puta in Lake Timsah. Three age groups from I to III years are encountered. The mean observed lengths at the different age groups are 8.71, 12.62 and $14.81 \mathrm{~cm}$, respectively. Apparently, no literature related to the age of this species was found.

The overall sex ratio of females to males $T$. puta is $1.2: 1$ indicating that the females are predominant during all seasons of the year. Similar observation was recorded in Terapon jarbua, from Tamshui River (Miu et al., 1990) in which the female to male sex ratio is $1.8: 1$. The predominance of females may be attributed to the male fertilizing efficiency (Salama, 1996) or to the fact that females consume more energy for environmental adaptation than males for the reproduction (Liang et $a l ., 2005)$ or males may not commonly inhabit the depth zone, where the majority of fishing efforts for this species is concentrated (Abaszadeh et al., 2013).On the other hand, Nandikeswari et al. (2013 and 2014 a) observed that males of T. puta and Terapon jarbua, from Puducherry (Pondicherry) coast, are dominant in the population and the overall sex ratio of females to males is 1:1.06 and 1:1.28, respectively. The variability of sex ratio in fishes may be due to their selective natural and fishing mortalities between sexes; or by the segregation of the sexes through various periods of the year, including segregation resulting from sex difference in age and size at maturity (Smith, 1956).

Knowledge of the spawning season of fish species gives an indication for the appropriate time for the closure of the fishery so as to protect the spawning stock biomass. It is noteworthy of mentioning that $T$. puta, from Lake Timsah has a prolonged spawning season that extends from early Spring till late Summer. This result coincides with that of Nandikeswari and Anandan (2013) who reported that $T$. puta, from Nallavadu coast has a prolonged spawning season extending from March till October. Conversely, it contradicts with that of Ben-Tuvia (1986) who stated that T. puta, from Bardawil Lagoon and the Mediterranean coast of Sinai has a single spawning season that occurs in Summer.

In the present study, it is noted that values of the absolute fecundity of T. puta increase proportionally with the fish total body length and total body weight. These observations coincide with those reported for $T$. puta, from Nallavadu coast (Nandikeswari and Anandan, 2013) and Terapon jarbua, respectively, from Pondicherry coast (Nandikeswari et al., 2014 a). Generally, the fecundity varies not only in the different species, but also in the same species in the different years or different environmental conditions (Latif and Shenouda, 1973). The observed absolute fecundity of $T$. puta ranges between 20437and 45272.83 eggs for fish with the mean total body length ranging from 9.9 to $12.35 \mathrm{~cm}$. However, it ranges from 25190.12 to 46508 eggs for fish with the mean body weight ranging from 16.54 to $25.19 \mathrm{gm}$. Higher absolute fecundity values were recorded for the same fish species, from Nallavadu coast (Nandikeswari and Anandan, 2013) in which the fecundity ranges from 20002 to 123042 eggs in fish between 13.4 to $21.9 \mathrm{~cm}$ total body length and 30 to $78 \mathrm{gm}$ total body weight. 
It is noteworthy of mentioning that the highest significant relationship is found between the logarithmic values of both the mean observed absolute fecundity and the mean total body weight, with the highest correlation coefficient $\left(\mathrm{r}^{2}=0.999\right)$. The total body weight is, consequently, the best indicator of the fecundity of $T$. puta. These observations coincide with those reported in Carassius auratus, from Rajshahi, Bangladesh (Amin et al., 2013) and in Pterophyllum scalare, from the same locality (Mazumder et al., 2013). However, Nandikeswari and Anandan (2013), in T. puta from Nallavadu coast, and Nandikeswari et al. (2014 a), in Terapon jarbua from Pondicherry coast, reported that the gonad weight is considered the best indicator of the fecundity of the aforementioned fish species, while the total body length occupies the subsequent rank. Moreover, Bagenal (1967), in some teleost fishes, explained the higher correlation of the absolute fecundity with the total body length than with the total body weight, to the stability of the fish length and the variability of its weight.

The recommendation of the present study is to prevent fishing of $T$. puta in Lake Timsah during the spawning season, which extends from April to August, or use nets with wider meshes in order to protect the spawning biomass of $T$. puta resources.

\section{REFERENCES}

Abaszadeh, A.; Keivany, Y.; Soofiani, N. M. and Falahatimarvast, A. (2013). Reproductive biology of the greater lizardfish, Saurida tumbil (Bloch, 1795), in Bushehr coastal waters of Iran.Turk. J. Zool., 37: 717-722.

Alwany, M. A. and Hassan, E. M. (2008). Otolith morphology and body size relationships for selected fishes in Suez Canal and Gulf of Suez. Catrina, 3(3): 55-63.

Amin, R.; Mazumder, F.; Nargis, A.; Khatun, M. and Talukder, D. (2013). Reproductive periodicity, fecundity and sex ratio of goldfish, Carassius auratus, (Perciformes: Cyprinidae) under laboratory condition. J. Agric. Vet. Sci., 3(1):36-41.

Bagenal, T. B. (1967). A short review of fish fecundity. In: "The Biological Basis of Freshwater Fish Production". Gerking, S. D. (ed.).Blackwell Sci. Pub., Oxford, England. Pp.: 89-111.

Ben-Tuvia, A. (1986). Teraponidae. In: "Fishes of the Northeastern Atlantic and the Mediterranean". Whitehead, P. J. P.; Bauchot, M. L.; Hureau, J. C.; Nielsen, J. and Tortonese, E. (eds.). Vol. 2. UNESCO, Paris. Pp: 797-799.

Edelist, D. (2012). New length-weight relationships and $\mathrm{L}_{\max }$ values for fishes from the southeastern Mediterranean Sea. J. Appl. Ichthyol., 30(3): 521-526.

El-Ganainy, A. A., (1992). Biological Studies on lizard fishes, Saurida undosquamis (Pisces: Synodontidae) from the Gulf of Suez. M.Sc. thesis, Fac. Sci, Ain Shams Univ., Cairo, Egypt.

Golani, D.; Orsi-Relini, L.; Massuti, E. and Quignard, J. P. (2002).CIESM Atlas of Exotic Species in the Mediterranean. Vol. 1: Fishes. Briand, F. (ed.). CIESM Pub., Monaco.

Holden, M. J. and D. F. Raitt, D. F. (1974). Manual of fisheries science part 2- Methods of resource investigation and their application. FAO Fish. Tech. Pap. (115) Rev. 1: $1-214$.

Hussain, S. M.; Paperno, R. and Khatoon, Z. (2010). Length-weight relationships of fishes collected from the Korangi-Phitti Creek area (Indus delta, northern Arabian Sea). J. Appl. Ichthyol. 26: 477-480.

Isa, M. M.; Abdul Basri, M. N.; Zawawi, M. Z. M.; Yahya, K. and Nor, S. A. M. (2012). Length-weight relationships of some important estuarine fish species from Merbok estuary, Kedah. J. Nat. Sci. Res., 2(2): 8- 17. 
Khan, S.; Khan, M. A. and Miyan, K. (2011). Comparison of age estimates from otoliths, vertebrae, and pectoral spines in African sharptooth catfish, Clarias gariepinus (Burchell). Est. J. Ecol., 60(3): 183-193.

Latif, A. F. A. and Shenouda, T. H. S (1973). Studies on Saurida undosquamis (Richardson) from the Gulf of Suez. Bull. Inst. Oceanogr.Fish., 3:183-202.

Lavergne, E.; Zajonz, U. and Sellin, L. (2013). Length-weight relationship and seasonal effects of the Summer monsoon on condition factor of Terapon jarbua (Forsskål, 1775) from the wider Gulf of Aden including Socotra island. J. Appl. Ichthyol., 29(1): 274- 277.

Le Cren, D. E. (1951). The length-weight relationship and seasonal cycle in gonad weight and condition in the perch (Perca fluviatilis).J. Anim. Ecol.,20(2): 201-219.

Liang, S. H.; Wu, H. P. and Shieh, B. S. (2005).Size structure, reproductive phenology and sex ratio of an exotic armored catfish (Liposarcus multiradiatus) in the Kaoping River of southern Taiwan. Zool. Stud., 44(2): 252-259.

Mazumder, F.; Nargis, A.; Amin, R. and Khatun, M. (2013). Reproductive periodicity, fecundity, sex ratio and parental care of anglerfish, Pterophyllum scalare, (Perciformes: Cichlidae) under laboratory condition. J. Adv. Sci. Res., 4(3): 6-11.

Miu, T. C.; Lee, S. C. and Tzeng, W. N. (1990).Reproductive biology of Terapon jarbua from the Estuary of Tamshui River. J. Fish. Soc. Taiwan, 17(1): 9-20.

Nandikeswari, R. and Anandan, V. (2013).Analysis on gonadosomatic index and fecundity of Terapon puta from Nallavadu coast Pondicherry. Int. J. Sci. Res. Pub., $3(2)$.

Nandikeswari, R.; Sambasivam, M. and Anandan, V. (2013). Study on sex ratio of Terapon puta (Cuvier, 1829) from Pondicherry coast. J. Environ. Sci. Comput. Sci. Eng. Technol., 4(2): 1396-1400.

Nandikeswari, R..; Sambasivam, M. and Anandan, V. (2014 a).Estimation of fecundity and gonadosomatic index of Terapon jarbua from Puducherry coast, India. Int. J. Biol. Vet. Agric. Food Eng., 8(1): 61-65.

Nandikeswari, R.; Sambasivam, M. and Anandan, V. (2014 b).Length-weight relationship of Terapon jarbua (Forsskal, 1775) from Puducherry waters. Int. J. Biol. Biomol. Agric. Food Biotechnol., 8(3): 277-281.

Nelson, J. S. (2006). Fishes of the World. $4^{\text {th }}$ edition. John Wiley \& Sons Inc., New York.

Nikolsky, G. V. (1963). The Ecology of Fishes. $1^{\text {st }}$ edition.Acad.Press, London \& New York.

Petrakis, O. and Stergiou, K. I. (1995). Weight-length relationships for 33 fish species in Greek waters. Fish. Res., 21: 465-469.

Phelps, Q. E.; Edwards, K. R. and Willis, D. W. (2007). Precision of five structures for estimating age of common carp. N. Amer. J. Fish. Manage.,27:103-105.

Ricker, W. E. (1973). Linear regression in fisheries research. J. Fish. Res. Board Can., 30: 409-434.

Salama, M. E. (1996). Effects of sex ratio and feed quality on mass production of Nile tilapia, Oreochromis niloticus (L.), fry. Aquacult. Res., 27(8): 581-585.

Secor, D. H.; Trice, T. M. and Hornick, H. T. (1995).Validation of otolith-based ageing and comparison of otolith and scale-based ageing in mark-recaptured Chesapeake Bay striped bass, Morone saxatilis. Fish. Bull., 93: 186-190.

Sinovcic, G.; Franicevic, M.; Zorica, B. and Ciles-Kec, V. (2004). Length-weight and length-length relationships for 10 pelagic fish species from the Adriatic Sea (Crotia). J. Appl. Ichthyol., 20: 56- 158.

Smith, S. (1956). Life history of lake herring of Green Bay, Lake Michigan.Fish. Bull., 57:87-138

Staples, D. J. (1971). Methods of ageing red gurnard (Teleosti: Triglidae) by fin rays and otoliths. New Zealand J. Mar. Freshwater Res., 5(1): 70-79. 
Strum, L. M. G., (1978). Aspects of the biology of Scombemorus maculatus (Mitchill) in Trinidad. J. Fish Biol., 13(2): 155-172.

Taskavak, E. and Bilecenoglu, M. (2001). Length-weight relationship for 18 lessepsian (Red Sea) immigrant fish species from the eastern Mediterranean coast of Turkey. J. Mar. Biol. Ass. U. K., 81(5): 895-896.

Vari, R. P. (2001). Terapontidae. In: "The Living Marine Resources of the Western Central Pacific". Carpenter K. E. and Niem V. H. (eds.). FAO, Rome. Pp. 33053316.

Vicentini, R. N. and Araujo, F. G. (2003). Sex ratio and size structure of Micropogonias furnieri (Desmarest, 1823) (Perciformes, Sciaenidae) in Sepetiba Bay, Rio de Janeiro, Brazil. Braz. J. Biol., 63(4): 559-566.

Wang, X. H.; Qiu, Y. S.; Zhu, G. P.; Du, F. Y.; Sun, D. R. and Huang, S. L. (2011). Length-weight relationships of 69 fish species in the Beibu Gulf, northern South China Sea. J. Appl. Ichthyol., 27: 959-961.

\section{ACKNOWLEGMENT}

The authors would like to express their deepest appreciation and sincere thanks to Prof. Dr. Magdy Tawfik Khalil, Professor of Aquatic Ecology, Zoology Department, Faculty of Science, Ain Shams University, for his support and guidance during the field work.

\footnotetext{
ARABIC SUMMARY

دراسات بيولوجية على أسماك التير ابون بوتا فى بحيرة التمساح

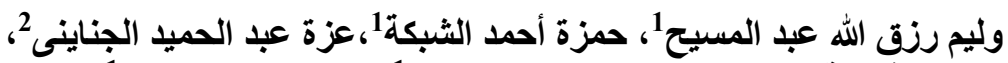

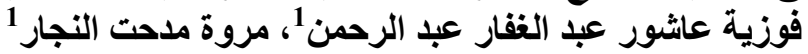

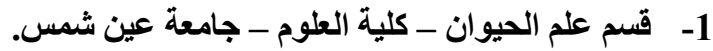

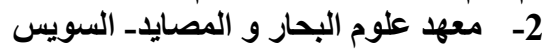

يهدف البحث الحالى إلى دراسة بعض الصفات البيولوجية لأسماك التيرابون بوتا في بحيرة التمساح

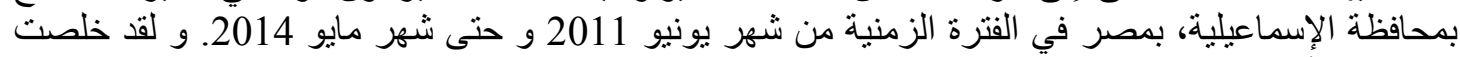

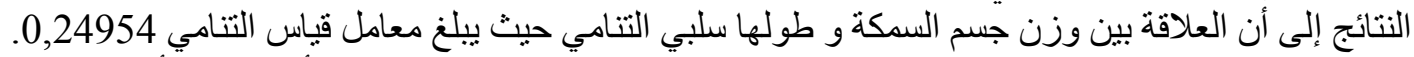

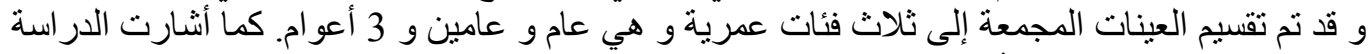

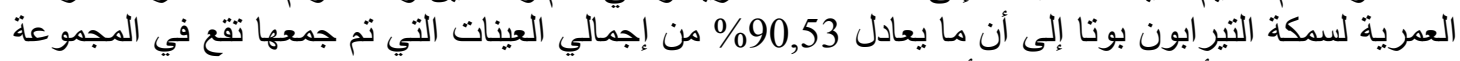

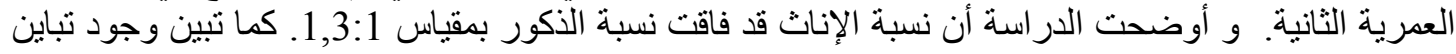

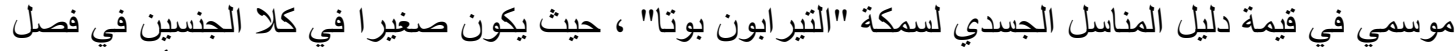

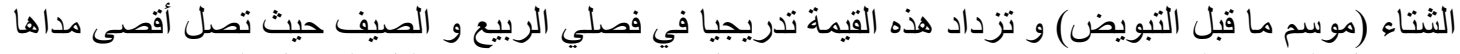

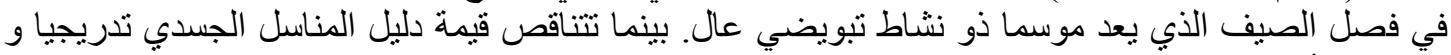

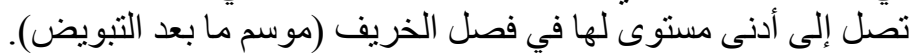

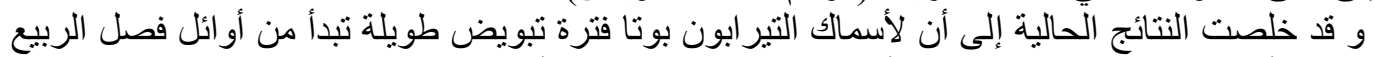

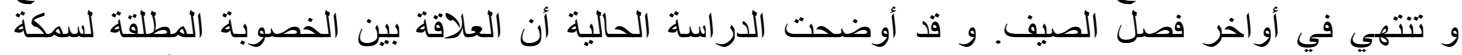

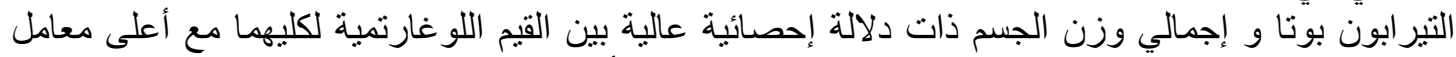
إرتباطو الذي يساوي 0,999 و من ثم يعتبر إجمالي وزن الجسم أفضل مؤشر لخصن لخصوبة سمكة التير ابون بوتا.
} 